\title{
NILAI MANFAAT DAN TINGKAT PENERAPAN MATERI PELATIHAN LITERASI DAN EDUKASI KEUANGAN (PLEK)
}

\author{
NINING HARIYANI \\ Widyaiswara Ahli Madya, Balai Besar Pelatihan Pertanian Ketindan \\ e-mail: nininghariyani83@gmail.com
}

\begin{abstract}
ABSTRAK
Rendahnya kesadaran dan kemampuan dalam pencatatan dan pengelolaan keuangan usahatani dan rumah tangga petani menyebabkan kesejahteraan kurang dirasakan oleh petani. Petani selama ini masih berorientasi pada kegiatan produksi dan belum mengarah pada bisnis yang menguntungkan melalui pengelolaan keuangan yang profesional. Pelatihan merupakan salah satu kegiatan yang dilakukan sebagai upaya untuk memberikan literasi dan edukasi keuangan baik usahatani maupun rumah tangga petani. Penelitian ini bertujuan untuk mengetahui nilai manfaat dan tingkat penerapan materi pelatihan literasi dan edukasi keuangan yang terdiri dari 2 materi inti yaitu pengelolaan keuangan usahatani dan pengelolaan keuangan rumah tangga. Metode penelitian menggunakan purposive sampling dengan responden alumni peserta pelatihan literasi dan edukasi keuangan tahun 2019 dan 2020 yang berasal dari Kabupaten Tuban, Ngawi, Lamongan, Madiun dan Jombang Provinsi Jawa Timur sebanyak 29 orang. Hasil penelitian menunjukkan bahwa kedua materi dinilai bermanfaat yaitu sebesar 4,35 dan 4,27 serta tingkat penerapan materi sebesar 3,23 dan 3,07 atau masih 50\% dari indikator hasil pembelajaran yang ditetapkan. Nilai manfaat berkorelasi secara positif terhadap penerapan kedua materi pelatihan. Perlu perbaikan modul pelatihan agar lebih sederhana, mudah dipahami dan diterapkan oleh peserta serta pendampingan yang intensif dari penyuluh pertanian setempat agar penerapan materi lebih optimal dan bermanfaat dalam kegiatan sehari-hari.
\end{abstract}

Kata Kunci: pengelolaan keuangan, nilai manfaat, penerapan pelatihan

\section{ABSTRACT}

The lack of awareness and ability in recording and managing the finances of farming and farmer households causes farmers can't get a real of their welfare. Farmers are still oriented to production activities and have not led to a profitable business through professional financial management. Training is one of the activities carried out as an effort to provide financial literacy and education for farming and farmer households. This study aims to determine the value of benefits and the level of application of financial literacy and education training materials which consist of 2 core materials, namely farming finance management and household financial management. The research method uses purposive sampling with 29 respondents from the Tuban, Ngawi, Lamongan, Madiun and Jombang regencies of East Java Province as participants in financial literacy and education training in 2019 and 2020. The results showed that the two materials were considered useful about 4.35 and 4.27 and the level of application of the materials was still at $50 \%$ or about 3.23 and 3.07 from the specified learning outcome indicators. The value of benefits is positively correlated with the application of the two training materials.It is necessary to improve the training module to make it simpler, easier to understand and aplicable by participants as well as intensive assistance from local extention officer so the material can be applied more optimally in farmer daily activities.

Keywords: financial management, value of benefits, application of training

\section{PENDAHULUAN}

Pengelolaan keuangan usahatani dan rumah tangga petani penting dilakukan untuk mengetahui sejauhmana tingkat kesejahteraan petani dalam mengelola usahanya. Selama ini petani masih berorientasi terhadap produksi dan belum mengarah pada usaha yang berorientasi bisnis. Usaha yang menguntungkan petani tentu tidak lepas dari aktivitas pencatatan dan pengelolaan keuangan baik dalam kegiatan usahatani maupun rumah tangga untuk menjamin 
kesejahteraan keluarga petani. Rendahnya kesadaran dan pengetahuan petani menyebabkan banyak petani yang enggan melakukan pencatatan apalagi melakukan pengelolaan usahatani dan rumah tangganya secara profesional. Salah satu upaya yang dapat dilakukan untuk meningkatkan kompetensi petani dalam pengelolaan keuangan usahatani dan rumah tangga petani adalah melalui pelatihan literasi edukasi keuangan bagi petani.

Penyelenggaraan pelatihan tersebut idealnya bertujuan untuk mewujudkan sumberdaya manusia petanian yang memenuhi standar sesuai tugas dan pekerjaannya, namun hasil pelatihan tersebut dianggap belum mampu meningkatkan kompetensi alumni peserta pelatihan secara optimal karena penilaian terhadap materi tidak sebanding dengan penerapan materi di tempat kerjanya. Banyak faktor yang dapat memicu adanya kesenjangan terkait penilaian dan penerapan materi tersebut, seperti motivasi kerja yang rendah, komitmen dalam melaksanakan tugas/pekerjaan masih rendah, kompetensi yang belum sesuai standar, kekurangan modal kerja dan lain sebagainya.

Lebih lanjut, berbagai kalangan juga beranggapan bahwa tidak ada perbedaan hasil yang mencolok antara setelah pelatihan dengan sebelum pelatihan sehingga program pelatihan dianggap hanya menghabiskan anggaran dan bukan menjawab diskrepansi kerja sesuai dengan kebutuhan peserta pelatihan. Oleh karena itu, guna menjawab hal permasalahan tersebut dan mengetahui sejauhmana penerapan materi pelatihan oleh alumni peserta pelatihan serta memperoleh informasi dan umpan balik bagi penyempurnaan program dan penyelenggaraan pelatihan yang akan datang maka perlu dilakukan evaluasi pasca pelatihan.

Penyelenggaraan pelatihan diarahkan untuk meningkatkan kompetensi sumberdaya manusia (SDM) pertanian baik aparatur maupun non aparatur pertanian, sehingga mampu melaksanakan tugas fungsi/pekerjaan secara inovatif, kreatif, profesional dan berwawasan global. Upaya peningkatan kompetensi SDM tersebut dapat diwujudkan apabila penyelenggaraan pelatihan pertanian dikelola dengan baik mulai dari perencanaan, pelaksanaan maupun monitoring dan evaluasi termasuk evaluasi pasca pelatihan.

Evaluasi pascapelatihan bertujuan untuk mengetahui penerapan hasil pelatihan para alumni peserta pelatihan sesuai dengan tugas dan fungsi/pekerjaan di tempat tugas/tempat usahanya. Hal ini perlu dilakukan untuk menghasilkan mutu alumni peserta pelatihan atau purnawidya yang memenuhi standar sesuai dengan kebutuhan tugas dan fungsi/pekerjaan di tempat tugas/tempat usahanya dan memberikan masukan terhadap program pelatihan ke depan.

Kompetensi alumni peserta pelatihan setelah mengikuti proses berlatih perlu dievaluasi secara sistematis berdasarkan kaidah-kaidah sistem evaluasi standar, dengan menggunakan instrumen sebagai alat ukur yang sahih dan objektif, sehingga dapat dipertanggungjawabkan secara ilmiah sebagaimana diatur dalam petunjuk pelaksanaan bimbingan lanjutan pendidikan dan pelatihan serta petunjuk pelaksanaan evaluasi pasca pendidikan dan pelatihan pertanian Nomor: 01/Permentan/OT.140/J/10/2011.

Evaluasi pasca pelatihan pertanian merupakan serangkaian kegiatan yang dilakukan secara teratur dan sistematis, untuk mengetahui tingkat penerapan hasil diklat oleh peserta dan peningkatan kinerja peserta serta organisasi yang dimulai dari pengembangan instrumen, pengumpulan dan analisis data serta penafsiran temuan dengan tujuan untuk memperoleh umpan balik dan mengetahui efektivitas diklat yang dilaksanakan (Ratna, 2016).

\section{METODE PENELITIAN}

Penelitian dilaksanakan di 5 Kabupaten yaitu Tuban, Ngawi, Lamongan, Madiun dan Jombang Provinsi Jawa Timur. Penelitian dilakukan Bulan Oktober sampai November 2021. Responden penelitian adalah alumni peserta pelatihan literasi dan edukasi keuangan Balai Besar Pelatihan Pertanian Ketindan mulai tahun 2019 sampai dengan 2020 yang berada di wilayah pengembangan program Integrated Participatory Development and Management Irrigation Program (IPDMIP) Badan Penyuluhan dan Pengembangan Sumberdaya Manusia Pertanian, Kementerian Pertanian sebanyak 29 orang. Metode penelitian ini menggunakan purposive sampling dimana jumlah responden ditentukan oleh masing - masing Koordinator Lapangan 
kegiatan IPDMIP di Dinas Pertanian Kabupaten dengan memilih 5-6 orang alumni peserta pelatihan yang berasal dari unsur petani tiap Desa/Kecamatan sesuai dengan anggaran program yang tersedia. Teknik analisis data dilakukan dengan statistik deskriptif dengan teknik kategorisasi. Kategorisasi dalam penelitian ini yaitu:

Tabel 1. Tabel Kategori Tingkat Manfaat Materi Pelatihan

\begin{tabular}{clc}
\hline No. & Nama Bagian & Kategori \\
\hline 1. & $>4,5$ & Sangat bermanfaat \\
2. & $3,51-4,49$ & Bermanfaat \\
3. & $2,51-3,49$ & Ragu-ragu \\
4. & $1,51-2,5$ & Kurang bermanfaat \\
5. & $\leq 1,5$ & Sangat kurang bermanfaat \\
\hline
\end{tabular}

Tabel 2. Tabel Katogori Tingkat Penerapan Materi Pelatihan

\begin{tabular}{clc}
\hline No. & Nama Bagian & Kategori \\
\hline 1. & $>4,5$ & Diterapkan $>75 \%$ \\
2. & $3,51-4,49$ & Diterapkan $75 \%$ \\
3. & $2,51-3,49$ & Diterapkan $50 \%$ \\
4. & $1,51-2,5$ & Diterapkan $25 \%$ \\
5. & $\leq 1,5$ & Belum diterapkan \\
\hline
\end{tabular}

\section{HASIL DAN PEMBAHASAN}

\section{Hasil}

Hasil kegiatan evaluasi pasca pelatihan literasi dan edukasi keuangan (PLEK) IPDMIP adalah sebagai berikut:

1. Analisis Deskriptif

a. Materi Pengelolaan Keuangan Usahatani

Rata-rata penilaian alumni peserta terhadap materi pengelolaan keuangan usahatani adalah sebesar 4,35 dengan kategori bermanfaat. Selanjutnya rata-rata penerapan terhadap materi sebesar 3,23 dengan kategori diterapkan 50\%. Adapun tingkat penilaian dan penerapan materi pengelolaan keuangan usahatani dapat dilihat pada gambar 1 .

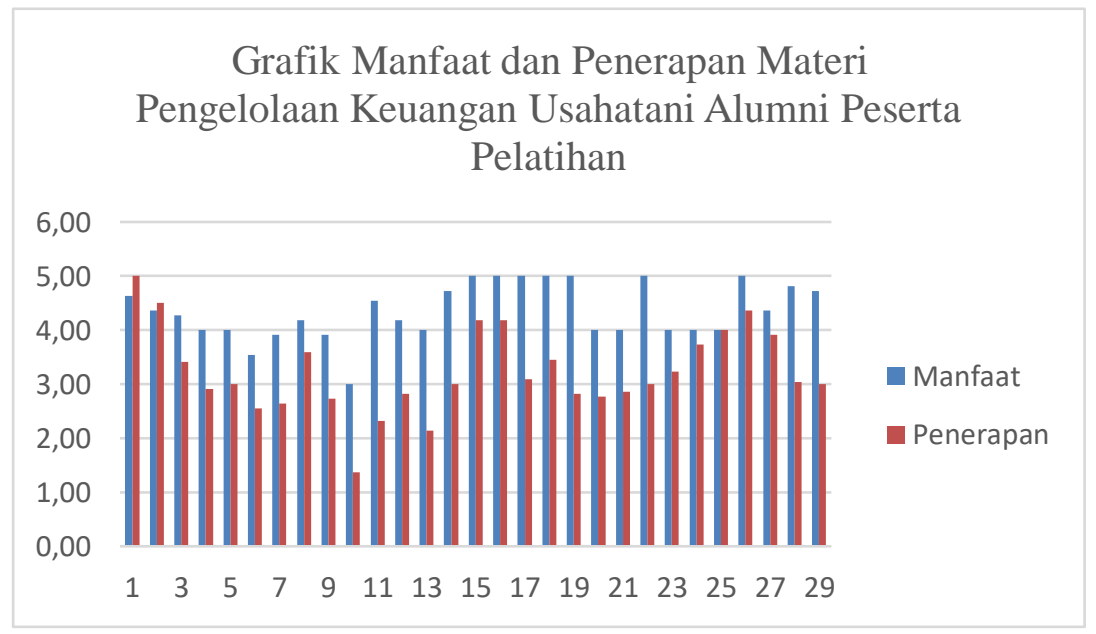

\section{Gambar 1. Grafik Manfaat dan Penerapan Materi Pengelolaan Keuangan Usahatani Alumni Peserta Pelatihan}

b. Materi Pengelolaan Keuangan Rumah Tangga

Rata-rata penilaian alumni peserta terhadap materi pengelolaan keuangan rumah tangga adalah sebesar 4,27 dengan kategori bermanfaat. Selanjutnya rata-rata penerapan 
terhadap materi sebesar 3,07 dengan kategori diterapkan 50\%. Adapun tingkat penilaian dan penerapan materi pengelolaan keuangan rumah tangga dapat dilihat pada gambar 2.

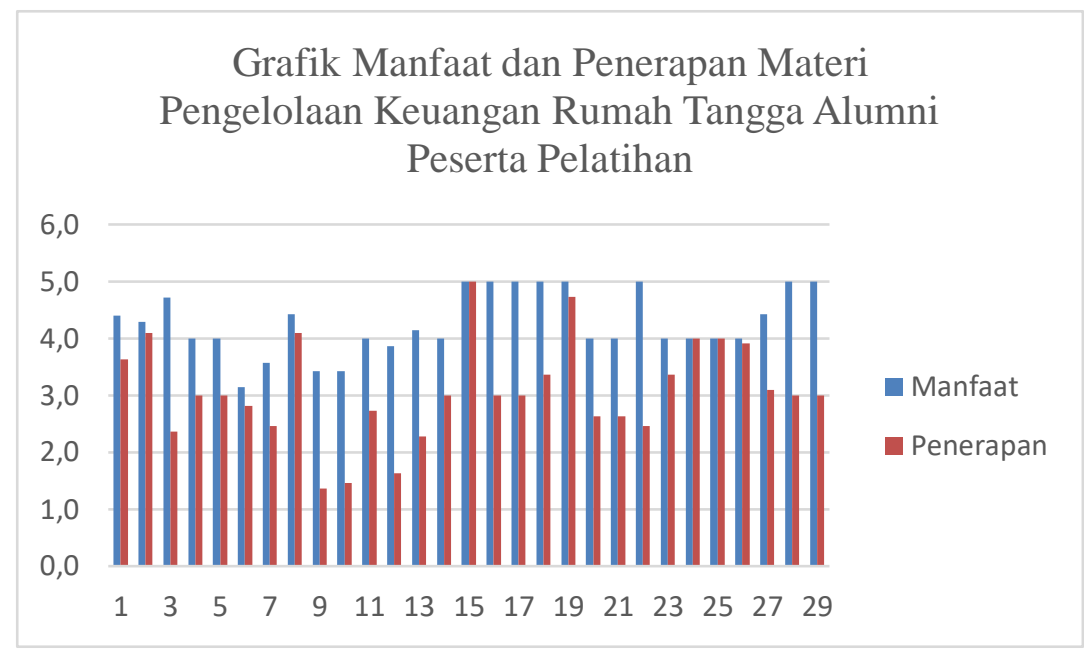

\section{Gambar 2. Grafik Manfaat dan Penerapan Materi Pengelolaan Keuangan Rumah Tangga Alumni Peserta Pelatihan}

2. Analisis Korelasi

Dasar pengambilan keputusan untuk analisis korelasi dapat ditentukan dari nilai signifikansi. Jika nilai signifikansi $(\alpha)<0,05$ maka berkorelasi, jika sebaliknya maka tidak berkorelasi. Pedoman yang dapat digunakan untuk menginterpretasikan koefisien korelasi adalah 0,00-0,199 untuk kategori sangat rendah, 0,20-0,399 kategori rendah, 0,40-0,599 kategori sedang, 0,60-0,799 kategori kuat dan 0,80 -1,000 kategori sangat kuat. (Sugiyono, 2007). Nilai korelasi (r) berkisar antara 1 sampai -1, nilai semakin mendekati 1 atau -1 berarti hubungan antara dua variabel semakin kuat, sebaliknya nilai mendekati 0 berarti hubungan antara dua variabel semakin lemah. Nilai positif menunjukkan hubungan searah (X naik maka Y naik) dan nilai negatif menunjukkan hubungan terbalik (X naik maka $\mathrm{Y}$ turun).Berdasarkan hasil korelasi antara nilai manfaat dan penerapan materi pengelolaan keuangan usahatani diperoleh nilai $\alpha<0,05$ yaitu sebesar 0,006 artinya terjadi korelasi dengan nilai Pearson Corelation sebesar 0,502 yang artinya tingkat hubungan antara manfaat dan penerapan materi dalam kategori sedang. Sedangkan nilai manfaat dan penerapan materi pengelolaan keuangan rumah tangga diperoleh nilai $\alpha<0,05$ yaitu sebesar 0,019 artinya terjadi korelasi dengan nilai Pearson Corelation sebesar 0,434 yang artinya tingkat hubungan antara manfaat dan penerapan materi dalam kategori sedang.

\section{Pembahasan}

Hasil analisis data menunjukkan bahwa 2 materi inti yang disajikan dalam pelatihan literasi dan edukasi keuangan (PLEK) IPDMIP dinilai peserta bermanfaat untuk melaksanakan kegiatan sehari-hari baik untuk tujuan usahatani maupun pengelolaan keuangan rumah tangga, namun pada pascapelatihan masih diterapkan 50\% dari keseluruhan indikator hasil belajar. Hal ini disebabkan karena petani belum terbiasa melakukan pencatatan dan pengelolaan keuangan baik usahatani maupun rumah tangga sesuai dengan format modul PLEK IPDMIP. Sebagian besar responden juga berpendapat bahwa format lebih rumit dari yang biasa mereka kerjakan dan perlu disederhanakan. Responden juga masih enggan melakukan pencatatan keuangan dan merasa takut bila setelah dilakukan analisis hasilnya merugi atau defisit. Lebih lanjut waktu pelaksanaan pelatihan yang relatif singkat juga menjadi alasan responden terhadap kurangnya pemahaman dan penerapan materi pascapelatihan. Oleh karena itu walaupun peserta menilai 
bahwa materi bermanfaat namun ternyata peserta belum mampu menerapkan secara keseluruhan materi secara optimal.

Northcott, D., \& Dollin (2000) dalam penelitiannya menyampaikan bahwa perlu adanya praktik akuntansi dalam sebuah rumah tangga petani agar mereka dapat mengelola keuangan rumah tangga dengan baik dan benar. (Manurung, D. T., \& Sinton, J. (2013) dalam penelitiannya juga menambahkan bahwa terdapat beberapa aspek penting yang harus ada dalam pengelolaan keuangan rumah tangga yaitu penganggaran, pencatatan, pengambilan keputusan dan perencanaan jangka Panjang agar dapat meningkatkan kesejahteraan petani ke depan.

\section{KESIMPULAN}

Materi pengelolaan keuangan usahatani dan keuangan rumah tangga dinilai bermanfaat oleh peserta namun tingkat penerapannya masih 50\% dari seluruh indikator hasil belajar, oleh karena itu perlu adanya perbaikan modul pelatihan agar lebih sederhana, mudah dipahami dan diterapkan oleh peserta. Selain itu, perlu diperhatikan penentuan durasi pelaksanaan pembelajaran disesuaikan dengan tujuan pembelajaran agar materi dapat bermanfaat dan dapat diterapkan dengan baik dan benar. Manfaat yang diperoleh dari materi pengelolaan keuangan usahatani dan rumah tangga berhubungan erat dengan tingkat penerapan petani, karena sangat bermanfaat untuk pelaksanaan kegiatan mereka sehari-hari. Minimnya pemahaman petani, pencatatan yang belum kontinyu, durasi waktu pelatihan dan modul yang rumit menyebabkan penerapan materi belum dapat dilakukan secara optimal dan membutuhkan pendampingan dari penyuluh pertanian setempat.

\section{DAFTAR PUSTAKA}

Anonimous. Peraturan Menteri Pertanian Nomor : 01/Permentan/OT.140/J/10/2011 Tentang Petunjuk Pelaksanaan Bimbingan Lanjutan Pendidikan dan Pelatihan Pertanian Serta Petunjuk Pelaksanaan Evaluasi Pasca Pendidikan Dan Pelatihan Pertanian. Kementerian Pertanian. Jakarta.

Manurung, D. T., \& Sinton, J. (2013).Urgensi Peran Akuntansi dalam Rumah Tangga. Jurnal Ilmiah Akuntansi dan Humanika, 892-909.

Mulyani, S., \& Budiman, N. A. (2018). Pentingnya Akuntansi Rumah Tangga dalam Meningkatkan Hidup Islami. Jurnal Ekonomi Syariah, 206-226.

Ratna, Sri. (2016). Modul Pendidikan Dan Pelatihan Kewidyaiswaraan Jenjang Menengah Mata Diklat Evaluasi Program Pasca Diklat. Modul. Lembaga Administrasi Negara Republik Indonesia. Jakarta

Subandriyo, Budi. 2020. Bahan Ajar Analisis Korelasi dan Regresi Diklat Statistisi Tingkat Ahli BPS Angkatan XXI. Badan Pusat Statistik. Jakarta.

Santoso, S. 2000. Buku Latihan SPSS Statistik Parametrik. Jakarta: Elex Media Komputindo

Sugiyono. 2007. Metode Penelitian Kuantitatif Kualitatif dan R\&D. Bandung: Alfabeta. 